\title{
Breast Feeding Practices: Comparison Between Educated and Illiterate Mothers in Kathmandu, Nepal
}

\author{
Milan Acharya ${ }^{1, *}$, Balram Devkota $^{1} \&$ Madhav Shrestha ${ }^{1}$ \\ ${ }^{1}$ Department of Health, Physical and Population Education, Sanothimi Campus, Tribhuvan University, \\ Kathamndu, Nepal \\ Correspondence: Milan Acharya, Department of Health, Physical and Population Education, Sanothimi Campus, \\ Tribhuvan University, Sanothimi, Kathmandu, Nepal. Tel: 98-41-630-800. E-mail: milanpanga123@gmail.com
}

"Milan Acharya is the principal author of this article

Received: July 18, 2019 Accepted: August 15, 2019 Online Published: August 16, 2019

doi:10.5539/gjhs.v11n10p105 URL: https://doi.org/10.5539/gjhs.v11n10p105

\begin{abstract}
Breastfeeding practice is important to determine the children's mortality and morbidity in the context of Nepal. The aim of this research was to compare the breastfeeding practices dominant among the educated and illiterate mothers of reproductive age (15-49) in Kathmandu Valley. The research was aimed at comparing the breastfeeding practices of women at different age groups, and exploring the issues of the frequency of breastfeeding among the educated and illiterate mothers. It was carried in four communities of Kirtipur Municipality that is located in the Valley. Educated mothers (from the School Leaving Certificate passed to Master's Degree holders) with their children were encompassed in this research study and the statistics and the meanings were collected by means of the piloted opinionaire on breastfeeding practices. The result showed that most of the mothers who were illiterate had better practices of breastfeeding as compared with the educated mothers. This research highlights the necessity for breastfeeding involvement packages particularly for the educated mothers who know the techniques of breastfeeding but don't want to do so on time due to a busy life schedule and concerning the appearance and beauty of their body.
\end{abstract}

Keywords: breastfeeding practices, comparative study, working mothers

\section{Introduction}

The appropriate and the correct breastfeeding practices are very essential elements of juvenile existence, age gaps with the brothers and/or sisters, and inhibition of babyhood contaminations and diseases. The importance of breastfeeding has been emphasized in various studies (Frank, Wirtz, Sorenson, \& Heeren, 1987; Gayen, Bhowmik, \& Nandy, 2019). The significance of special breastfeeding and its nourishing values of breast milk have been established (Arzu, Sujan, Paul, Ahmad, Juliana, \& Hossain, 2019; Rollins, Meda, Becquet, Coutsoudis, Humphrey, Jeffrey, \& Mcintyre, 2004). The importance of breastfeeding is totally determined by time interval, frequency per day, the infant/baby's age, weight, and physical movement. The habit and the practices of breastfeeding are different in different ethnic, and religious groups, communities and geographical regions. In the case of Kathmandu valley, Nepal, the practice of breastfeeding in the remote and dormitory towns as well as in the peripheral residents depends on the views the inhabitants of the specific community, which are affected by the norms and values of culture and socio-economic conditions of the community. Henceforth, the study with these associations benefits in positioning the breastfeeding practices which help in declining the prevalence of communicable diseases among the infants/babies.

Appropriate breastfeeding practices up to six months after the birth supplies almost all the required food nutrients to the infant/baby, which is the best and most economical way of reduciing infant mortality rate. A research study showed that "every year, 57,000 children five years of age lose their lives, among which $54 \%$ of deaths occur within the first month of life, $22 \%$ of the newborn's death can be prevented through breastfeeding within the first hour of birth" (Ministry of Health and Population [MOHP] [Nepal]). Currently, "only 53\% of babies in Nepal are breastfed exclusively until the age of 6 months and 35\% are breastfed within the first hour of birth" (ibid). At present, $11 \%$ children under five in Nepal are underweight and 29\% are wasted (Ministry of Health and Population 
[MOHP] [Nepal]).

Furthermore, a projected 1.3 million lives are lost each year due to insufficient breast feeding practices. Fewer than $35 \%$ of infants worldwide are breastfed during the first six months of life. Moreover, undernourishment is accountable for $1 / 3$ of the 8.8 million expiries per year among children under 5 years of age. Over two thirds of these expiries are repeatedly connected with unsuitable nourishing habits such as feeding cow/buffalo milk. "More than $15 \%$ of 24 lakh child deaths could be averted in India by optimal breastfeeding practices" (World Health Organization, 2007). According to Ekambaram, Bhat \& Ahamed, (2010), "breastfeeding is the ideal method suited for the physiological and psychological needs of an infant" (p. 34). The mother's antibody present in the breast milk provides immunity to infants to protect from different diseases (World Health Organization, 2007). In this study, I am trying to look at the age variable with the breastfeeding of children among the mother who are educated and illiterate.

\section{Methods and Materials}

This comparative study was conducted in four communities of Kirtipur Municipality, which are attached to rural areas of Kathmandu Valley, Nepal from August to December of 2018. Verbal consent was taken from all the mothers and those who were not willing to participate were excluded. Luckily, $99 \%$ mothers agreed to participate in the study. A set of opinionaire of the Likert scale (strongly agree, agree, don't know, disagree and strongly disagree) was used. Over a period of 5 months, I reached the home of every mother, then they were provided with the sheet of opinionnaire of the total sample of 180. For those who could not read, I read the statements for them and ticked their opinions. The survey research approach was used in this study. A set of questionnaire was applied to gather the information. A total of 180 females of reproductive age (15-49) took part in the study.

I used the Cochran formula and the random sampling method in this research among the mothers of 180 , including 90 educated (SLC passed) and 90 illiterate. Going to four communities of Kirtipur municipality, namely, Panga, Bhanjal, Machhegaun and Dhalpa, 180 mothers were selected by simple random the questionnaire was distributed. It consisted of a 5 point Likert scale (strongly agree-5, agree-4, don't know-3, disagree-2 and strongly disagree 1). Consistency of the questionnaire was achieved using the Cronbach Alpha for all variables. Since all values were above 0.7 , all questions had acceptable consistency.

\section{Results and Discussion}

The result is based on the descriptive data as shown in the Tables (1-6) below.

Table 1. Distribution of illiterate mothers according to age

\begin{tabular}{llll}
\hline Respondents & Number & Age & Percentage \\
\hline & 32 & Between 15-19 & 17.77 \\
Illiterate mothers & 30 & Between 20-24 & 16.67 \\
& 17 & Between 25-29 & 9.44 \\
& 7 & Between 30-34 & 3.88 \\
\hline
\end{tabular}

Table 2. Distribution of educated mothers according to age

\begin{tabular}{llll}
\hline Respondents & Number & Age & Percentage \\
\hline & 2 & Between 15-19 & 1.11 \\
Educated mothers & 48 & Between 20-24 & 26.66 \\
& 7 & Between 25-29 & 3.88 \\
& 4 & Between 30-34 & 2.22 \\
& 2 & Above 35 & 1.11 \\
\hline
\end{tabular}


Table 3. Distribution of illiterate mothers according to occupation

\begin{tabular}{llll}
\hline Respondents & Number & Occupation & Percentage \\
\hline & 32 & Farming (agriculture) & 17.77 \\
Illiterate mothers & 4 & Animal husbandry & 2.22 \\
& 24 & Labour (house construction) & 13.33 \\
& 8 & Labour (daily wages in field) & 4.44 \\
& 22 & Nothing & 12.22 \\
\hline
\end{tabular}

Table 4. Distribution of educated mothers according to service

\begin{tabular}{llll}
\hline Respondents & Number & Occupation & Percentage \\
\hline & 41 & Nothing & 22.78 \\
Educated mothers & 38 & Teaching & 21.11 \\
& 2 & Engineer & 1.11 \\
& 1 & Doctor & 0.55 \\
\hline
\end{tabular}

Table 5. Distribution of qualification of educated mothers

\begin{tabular}{lllll}
\hline Respondents qualification & Under SLC & +2 passed & Bachelor level & Masters' level \\
\hline Number & 26 & 46 & 14 & 4 \\
Percentages & 14.44 & 25.55 & 7.77 & 2.22 \\
\hline
\end{tabular}

Table 6. Comparing breast feeding of illiterate and educated mothers regarding its frequency

\begin{tabular}{lllllll}
\hline \multirow{2}{*}{ Respondents } & \multicolumn{1}{l}{ Mean } & \multicolumn{1}{l}{} \\
\cline { 2 - 7 } & 4 times a day & 5 times a day & 6 times a day & 7 times a day & 8 times a day & Basic mean \\
\hline Illiterate & 3.43 & 3.45 & 2.87 & 3.24 & 3.22 & 3 \\
Educated & 3.69 & 3.91 & 3.64 & 3.79 & 3.82 & 0.30 \\
Mean difference & 0.46 & 0.46 & 0.23 & 0.55 & \\
\hline
\end{tabular}

As seen in Table 1, $17.77 \%$ of mothers were below the age of twenty and only $2.22 \%$ were above 35 whereas, 48 $(26.66 \%)$ out of $90(73.34 \%)$ were educated and were between $20-24$. This shows that the educated women give birth to the babies at a more appropriate age the illiterate ones. Thirty two (17.78\%) women out of 90 were engaged in agricultural practices and $22(12.22 \%)$ illiterate women were not doing any income generating activities. Furthermore, $41(27.78 \%)$ educated mothers were a not engaging in any jobs, either but they were taking care of their babies. Among the educated mothers, 26 (14.44\%) were under SLC, 46 (25.55\%) had attended higher secondary $(+2)$ education, $14(7.77 \%)$ were bachelors and only $4(2.22 \%)$ had gained the master's degree.

Table 7. t-test for comparing breast feeding practices among the educated and illiterate mothers of age 15-19

\begin{tabular}{lllllllllll}
\hline Index & Mothers & no & mean & SD & Mean difference & $\mathrm{t}$ & $\min$ & $\max$ & $\mathrm{df}$ & $\operatorname{Sig}(\mathrm{p})$ \\
\hline \multirow{2}{*}{ Breast feeding } & Educated & 90 & 32.32 & 5.11 & 7.04 & 14.21 & 9 & 45 & 179 & 0.05 \\
& Illiterate & 90 & 39.21 & 5.42 & & & & & & \\
\hline
\end{tabular}


Table 8. t-test for comparing breast feeding practices among the educated and illiterate mothers of age 20-24

\begin{tabular}{|c|c|c|c|c|c|c|c|c|c|c|}
\hline Index & Mothers & no & mean & SD & Mean difference & $\mathrm{t}$ & $\min$ & $\max$ & $\mathrm{df}$ & $\operatorname{Sig}(p)$ \\
\hline \multirow{2}{*}{ Breast feeding } & Educated & 90 & 29.31 & 3.21 & \multirow{2}{*}{9.32} & \multirow{2}{*}{12.52} & \multirow{2}{*}{5} & \multirow{2}{*}{50} & \multirow{2}{*}{179} & \multirow{2}{*}{0.05} \\
\hline & Illiterate & 90 & 38.63 & 5.76 & & & & & & \\
\hline
\end{tabular}

Table 9. t-test for comparing breast feeding practices among the educated and illiterate mothers of age 25-29

\begin{tabular}{|c|c|c|c|c|c|c|c|c|c|}
\hline Index & Mothers & no & mean & SD & Mean difference & $\mathrm{t}$ & $\min$ & $\max \quad \mathrm{df}$ & $\operatorname{Sig}(p)$ \\
\hline \multirow{2}{*}{ Breast feeding } & Educated & 90 & 24.95 & 3.43 & \multirow{2}{*}{6.72} & \multirow{2}{*}{10.54} & \multirow{2}{*}{7} & \multirow{2}{*}{35} & \multirow{2}{*}{0.05} \\
\hline & Illiterate & 90 & 31.67 & 5.98 & & & & & \\
\hline
\end{tabular}

Table 10. t-test for comparing breast feeding practices among the educated and illiterate mothers of age 30-34

\begin{tabular}{|c|c|c|c|c|c|c|c|c|c|}
\hline Index & Mothers & no & mean & SD & Mean difference & $\mathrm{t}$ & $\min$ & $\max$ & $\operatorname{Sig}(p)$ \\
\hline \multirow{2}{*}{ Breast feeding } & Educated & 90 & 25.65 & 3.6 & \multirow{2}{*}{2.78} & \multirow{2}{*}{9.11} & \multirow{2}{*}{6} & \multirow{2}{*}{30} & \multirow{2}{*}{0.05} \\
\hline & Illiterate & 90 & 27.43 & 4.9 & & & & & \\
\hline
\end{tabular}

Table 11. t-test for comparing breast feeding practices among the educated and illiterate mothers of age 35-39

\begin{tabular}{|c|c|c|c|c|c|c|c|c|c|}
\hline Index & Mothers & no & mean & SD & Mean difference & $\mathrm{t}$ & $\min$ & $\max$ & $\operatorname{Sig}(p)$ \\
\hline \multirow{2}{*}{ Breast feeding } & Educated & 90 & 30.45 & 4.6 & \multirow{2}{*}{3.32} & \multirow{2}{*}{7.92} & \multirow{2}{*}{5} & \multirow{2}{*}{23} & \multirow{2}{*}{0.05} \\
\hline & Illiterate & 90 & 25.32 & 2.5 & & & & & \\
\hline
\end{tabular}

Table 12. t-test for comparing breast feeding practices among the educated and illiterate mothers of age 40-44

\begin{tabular}{|c|c|c|c|c|c|c|c|c|c|}
\hline Index & Mothers & no & mean & SD & Mean difference & $\mathrm{t}$ & $\min$ & $\max \quad \mathrm{df}$ & $\operatorname{Sig}(p)$ \\
\hline \multirow{2}{*}{ Breast feeding } & Educated & 90 & 22.00 & 6.5 & \multirow{2}{*}{4.6} & \multirow{2}{*}{6.54} & \multirow{2}{*}{6} & \multirow{2}{*}{30} & \multirow{2}{*}{0.05} \\
\hline & Illiterate & 90 & 16.59 & 4.4 & & & & & \\
\hline
\end{tabular}

Table 13. t-test for comparing breast feeding practices among the educated and illiterate mothers of age 45-49

\begin{tabular}{lllllllllll}
\hline Index & Mothers & no & mean & SD & Mean difference & $\mathrm{t}$ & $\min$ & $\max$ & $\mathrm{df}$ & $\mathrm{Sig}(\mathrm{p})$ \\
\hline \multirow{2}{*}{ Breast feeding } & Educated & 90 & 16.0 & 5.7 & \multirow{2}{*}{6.4} & 3.53 & 4 & 21 & & 0.05 \\
& Illiterate & 90 & 12.44 & 2.8 & & & & & & \\
\hline
\end{tabular}

Results from Table 14 shows the Spearman correlation test i.e., correlation value $(\mathrm{r}=-0.39)$ and 0.04 level of significance level $(\alpha=0.04)$, at the confidence level of $95 \%$ and error level below 0.05 , then the correlation between the age of mothers and breast feeding practices is positive. In other words, any variation (increase or decrease) in one variable leads to the variation of the other. It means that the higher age of the mothers, the higher the breast feeding practices. Thus, the hypothesis is confirmed.

Table 14. Correlation test for the age status of both the groups of mothers

\begin{tabular}{|c|c|c|c|c|c|}
\hline Variables & $\begin{array}{l}\text { Measure of Variables } \\
\text { Correlation value }\end{array}$ & $\begin{array}{l}\text { Correlation } \\
\text { type }\end{array}$ & Statistics & Correlation value & Sig. \\
\hline Age of mothers & Sequential-sequential & Spearman & $\mathrm{r}$ & 0.39 & 0.05 \\
\hline
\end{tabular}

Table 14 shows the Spearmen correlation test i.e., correlation spearman $(r=-0.39)$ and the significance level $(\alpha=0.05)$, at $99 \%$ confidence level and error level below is 0.05 , then the correlation between the age of the 
mothers and breast feeding practice is positive. In other words, any variation (increase or decrease) in one variable leads to the variation of the other. It means that the higher the age of the mothers, the higher the breast feeding practices. Thus, the hypothesis is accepted.

Table 15. Multiple regression result of illiterate and educated mothers

\begin{tabular}{|c|c|c|c|c|c|}
\hline $\begin{array}{l}\text { Dependent } \\
\text { variable }\end{array}$ & Independent variable & $\mathrm{R}$ & $\mathrm{R}^{2}$ & Modified $\mathrm{R}^{2}$ & Standard error \\
\hline Breast feeding habits & Age, occupation and qualification of mothers & 0.59 & 0.476 & 0.369 & 9.46 \\
\hline
\end{tabular}

Based on multiple regression results, multiple regression coefficient for the breast feeding practices of mothers is $\mathrm{r}=0.59$; thus, the above variables are correlated with mother's age, occupation and qualification as much as 0.59 . Also, these variables identify $46.9 \%$ of the total variance of the dependent variable.

Table 16. Standardized coefficient of $\beta$

\begin{tabular}{|c|c|c|c|c|c|}
\hline \multirow{2}{*}{ Independent variables } & \multicolumn{2}{|c|}{ Unstandardized coefficient } & \multicolumn{3}{|c|}{ Standardized coefficient } \\
\hline & $\beta$ Estimation error & Estimated error & $\beta$ & $\mathrm{T}$ & Sig \\
\hline Fixed coefficient & 13.267 & 3.358 & - & 3.123 & 0.000 \\
\hline Age & 2.345 & 0.268 & 0.108 & 3.784 & 0.000 \\
\hline Occupation & 1.468 & 0.036 & 0.269 & 4.100 & 0.000 \\
\hline Qualification & 0.471 & 0.095 & 0.387 & 6.658 & 0.000 \\
\hline Cultural practices & -1.320 & 0.047 & 0.121 & 4.130 & 0.098 \\
\hline
\end{tabular}

The result of Table 16 is that the major variables such as age, occupation and the qualification have significant effects on mothers' breast feeding practices. The value $\beta$ of 0.269 has more than other variables and affects the practices more than others. Then, age 0.297 , and occupation 0.269 have the next effects on breast feeding practices. Among these variables, qualifications can't identify an independent variable.

\section{Discussion and Conclusion}

In this study, illiterate women in the dormitory towns have a good frequency of breast feeding. Most of the mothers had started breastfeeding practices and it was persistent to breastfeed up to 4 years. Other studies conducted in rural areas show that "almost all the mothers initiate breastfeeding to take care the health of their children"(Batal, Boulghourjian, Abdallah, \& Afifi, 2006). In the other studies (Haggerty \& Rutstein, 1999) a similar pattern is observed.

Breastfeeding should be conducted up to 7 times a day. This habit defends the infant/baby from under-nutrition, controls communicable diseases, and helps their physical and mental development. In this study more than fifty percent i.e., 115 out of $180(64 \%)$ of both the illiterate and educated mothers were adopting breastfeeding practices to their children and the remaining65 (34\%) of both types of mothers were not adopting the breast feeding practices at the right and required time. According to Kimani-Murage, Madise, Fotso, Kyobutungi, Mutua, Gitau, \& Yatich, (2011), the prevalence of infectious diseases which have a long term effect on the physical and mental development of the child. Research also indicates that premature mothers breastfeed less often than mature ones and they hold both positive and negative attitudes toward breastfeeding practices (Davara, Pandya, Chavda, Solanki, Mehta, \& Shringarpure, 2019; Hossain, Islam, Kamarul, \& Hossain, 2018).

This study aimed to compare the breast feeding practices of illiterate and educated mothers of Kirtipur municipality. In this study, a majority of the mothers had breast feeding at least four times a day. As a recommendation, it emphasizes the need for breastfeeding intervention programs especially for the educated mothers during office hours and during the day time for the illiterate mothers who are obliged to spend the day at the workplace. The information regarding the advantages and duration of breastfeeding needs to be provided for the community as a whole. 


\section{Authors' Contributions}

MA collected and analyzed the data, interpretation of the data and drafted the manuscript. BD and MS provided comments on the final manuscript. All authors read and approved the final version of the manuscript.

\section{Acknowledgements}

We would like to thank the respondent mothers who actively participated in this study. Also, we would like to thank to the respected teachers, seniors and professors of Health, Population and Physical Education for scholarly guidance and encouragement to prepare the article.

Any opinions, findings, and conclusions made here are those of the authors and the participants and should not be necessarily attributed to the Ministry of Health and Population (MoHP), Government of Nepal.

\section{Competing Interests Statement}

The authors declare that there are no competing or potential conflicts of interest.

\section{References}

Arzu, T., Sujan, A. K., Paul, D. K., Ahmad, T., Juliana, F. M., \& Hossain, S. (2019). Comparative Study of Growth Monitoring \& Promotion of Children with Special Care (IYCF Counseling) and without Special Care. American Journal of Food Science and Technology, 7(4), 104-112.

Batal, M., Boulghourjian, C., Abdallah, A., \& Afifi, R. (2006). Breast-feeding and feeding practices of infants in a developing country: a national survey in Lebanon. Public health nutrition, 9(3), 313-319. https://doi.org/10.1079/PHN2006860

Davara, K., Pandya, C., Chavda, P., Solanki, D., Mehta, K., \& Shringarpure, K. (2019). Feeding Practices by Mothers Having Children Under 6 Months of Age-A Community Based Study in Urban Slum Areas of Vadodara City. Community Med, 10(2), 86-90.

Ekambaram, M., Bhat, V., \& Ahamed, M. A. P. (2010). Knowledge, attitiude and practice of breastfeeding among postnatal mothers. Current Pediatric Research, 14(2), p119.

Frank, D. A., Wirtz, S. J., Sorenson, J. R., \& Heeren, T. (1987). Commercial discharge packs and breast-feeding counseling: effects on infant-feeding practices in a randomized trial. Pediatrics, 80(6), 845-854.

Gayen, G., Bhowmik, A., \& Nandy, M. (2019). Study of feeding practice and factors influencing it among preterm babies getting Kangaroo mother care in a Tertiary Care Hospital. Journal of Clinical Neonatology, 8(2), 85. https://doi.org/10.4103/jen.JCN_100_18

Haggerty, P. A., \& Rutstein, S. O. (1999). Breastfeeding and complementary infant feeding and the postpartum effects of breastfeeding.

Hossain, M., Islam, A., Kamarul, T., \& Hossain, G. (2018). Exclusive breastfeeding practice during first six months of an infant's life in Bangladesh: a country based cross-sectional study. BMC pediatrics, 18(1), 93. https://doi.org/10.1186/s12887-018-1076-0

Kimani-Murage, E. W., Madise, N. J., Fotso, J. C., Kyobutungi, C., Mutua, M. K., Gitau, T. M., \& Yatich, N. (2011). Patterns and determinants of breastfeeding and complementary feeding practices in urban informal settlements, Nairobi Kenya. BMC public health, 11(1), 396. https://doi.org/10.1186/1471-2458-11-396

Ministry of Health and Population [Nepal], New ERA, and ICF International Inc. (2012). Nepal Demographic and Health Survey 2011. Kathmandu, Nepal.

Rollins, N., Meda, N., Becquet, R., Coutsoudis, A., Humphrey, J., Jeffrey, B., ... \& Mcintyre, J. (2004). Preventing postnatal transmission of HIV-1 through breast-feeding: modifying infant feeding practices. Journal of $\begin{array}{lllll}\text { acquired immune deficiency syndromes } & \text { (1999), } & 35(2), & 188 .\end{array}$ https://doi.org/10.1097/00126334-200402010-00014

World Health Organization. (2007). Protein and amino acid requirements in human nutrition. World health organization technical report series, (935), 1.

\section{Copyrights}

Copyright for this article is retained by the author(s), with first publication rights granted to the journal.

This is an open-access article distributed under the terms and conditions of the Creative Commons Attribution license (http://creativecommons.org/licenses/by/4.0/). 